PERM JOURNAL OF PETROLEUM AND MINING ENGINEERING

ВЕСТНИК ПНИПУ. ГЕОЛОГИЯ. НЕФТЕЕАЗОВОЕ И ГОРНОЕ ДЕЛО

ISSN 2224-9923

Volume/ Toм 16 №3 2017

http://vestnik.pstu.ru/geo/

УДК 622.45-047.58

Article / Статья

(C) PNRPU / ПНИПУ, 2017

\title{
RESULTS OF MODELLING OF MINE VENTILATION WITH AIR CURTAIN INSTALLED INTO DOWNCAST AND UPCAST SHAFTS
}

\section{Aleksandr V. Nikolaev, Nikolay I. Alymenko', Anton A. Kamenskikh', Shtefan K. Fet ${ }^{2}$, Viktor A. Nikolaev}

Perm National Research Polytechnic University (29 Komsomolskiy av., Perm, 614990, Russian Federation)

${ }^{1}$ Mining Institute of the Ural Branch of the Russian Academy of Sciences - Branch of the Federal State Budgetary Institution of Science Perm

Federal Research Center of the Ural Branch of the Russian Academy of Sciences (78 Sibirskaya st., Building A, Perm, 614007, Russian Federation)

${ }^{2}$ TH Georg Agricola University of Applied Sciences (45 Kherner Shtrabe st., Bochum, 44787, Federal Republic of Germany)

\section{РЕЗУЛЬТАТЫ МОДЕЛИРОВАНИЯ ПРОЦЕССА ПРОВЕТРИВАНИЯ РУДНИКА ПРИ РАСПОЛОЖЕНИИ ВОЗДУШНОЙ ЗАВЕСЫ В ВОЗДУХОПОДАЮЩЕМ И ВЕНТИЛЯЦИОННОМ СТВОЛАХ}

\section{А.В. Николаев, Н.И. Алыменко ${ }^{1}$, А.А. Каменских ${ }^{1}$, Ш.К. Фет ${ }^{2}$, В.А. Николаев}

Пермский национальный исследовательский политехнический университет (614990, Россия, г. Пермь, Комсомольский пр., 29) ${ }^{1}$ Горный институт Уральского отделения Российской академии наук - филиал Федерального государственного бюджетного учреждения науки Пермского федерального исследовательского центра Уральского отделения Российской академии наук (614007, Россия, г. Пермь, ул. Сибирская, 78a)

${ }^{2}$ Высшая инженерная школа (Высшая школа технических наук) им. Георга Агриколы (44787, Германия, г. Бохум, Хернер Штрабе, 45)

Received / Получена: 07.06.2017. Accepted / Принята: 19.07.2017. Published / Опубликована: 15.09.2017

Key words:

air curtain, main ventilation fan, downcast shafts, upcast shafts, outside air leakage, mine air heater.

\begin{abstract}
Existing mine air heaters (MAH) that heat the air supplied into downcast shafts during the cold period are equipped with a heat channel. A part of the air from a MAH goes through a heat channel. Another part is sucked through a pit head by general depression created by a shaft main fan. That raises a problem of mixing of two air streams, which disturbs thermal regime in the shafts and could lead to violation of safety rules, in particular, create a breach of sealing of intertubular seals. Besides, there is a concern of energy saving during ventilation at underground mining enterprises. One of the reasons for energy efficiency reduce during air supply to a mine are external leaks appeared during ventilation by a suck method.

The article presents proposed solution for both problems using air curtain. During air preparation in the cold period, it is proposed to place air curtain in an air downcast shafts above the junction of a heat channel and a shaft. That is done in order to prevent air infiltration (sucking) through a pit head. According to the paper air curtain should be used in the ventilation shaft to decrease outside air leakage in order to increase energy efficiency of a main fan performance. It is determined during mathematical modelling (in SolidWorks Flow Simulation software) of ventilation and air preparation that air curtain can increase efficiency of MAH and decrease energy consumption on ventilation.
\end{abstract}

В существуюших шахтных калориферных установках (ШКУ), предназначенных для нагрева воздуха, подаваемого в воздухоподаюшие стволы в холодное время года, используется калориферный канал. Часть воздуха из ШКУ подается по калориферному каналу, а часть подсасывается через надшахтное здание за счет обшешахтной депрессии, создаваемой шахтной главной вентиляторной установкой (ГВУ). При этом возникает проблема депрессии, создаваемой шахтной главной вентиляторной установкой (ГВУ). При этом возникает проблема смешения этих двух потоков воздуха, вследствие чего нарушается тепловой режим в стволах, что может привести подземных горнодобывающих предприятиях особо остро стоит вопрос энергосбережения при проветривании. Одной из причин снижения энергоэффективности процесса подачи воздуха в рудник является наличие внешних утечек, возникающих при проветривании по всасывающему способу.

В статье приведено предлагаемое решение обеих задач посредством применения воздушной завесы. При осуществлении воздухоподготовки в холодное время года предлагается воздушную завесу размещать в воздухоподающем стволе выше места сопряжения калориферного канала со стволом для препятствия инфильтрации (подсоса) воздуха через надшахтное здание. Воздушную завесу в вентиляционном стволе в настоящей статье предлагается использовать для снижения внешних утечек воздуха с целью повышения энергоэффективности работы ГВУ. В ходе математического моделирования процесса проветривания и подготовки воздуха (в программном пакете SolidWorks Flow Simulation) установлено, что применение воздушной завесы в воздухоподаюшем стволе позволит повысить эффективность работы ШКУ, а в вентиляционном стволе - снизить затраты электроэнергии на проветривание.

Aleksandr V. Nikolaev (Author ID in Scopus: 56988627700$)-\mathrm{PhD}$ in Engineering, Associate Professor at the Department of Mine Electromechanics (mob, tel: +007 908 241 40 19, e-mail: nikolaev0811@mail.ru). The contact person.

Nikolay I. Alymenko (Author ID in Scopus: 54895153400) - Doctor of Engineering, Professor, Chief Research Fellow at the Laboratory of Geotechnological Processes and Mine Gas Dynamics (mob. tel.: +007 91278980 86, e-mail: nik.alymenko@yandex.ru).

Anton A. Kamenskikh - PhD in Engineering, Research Fellow at the Laboratory of Geotechnological Processes and Mine Gas Dynamics (mob. tel.: +007 909 7316944 , e-mail: anton.kamenskikh@mi-perm.ru).

Shtefan K. Fet - Doctor of Engineering, Professor, Head of the Department of Technology of Electric Drives and Transport Systems (mob. tel.: +490 234 9683642 , e-mail: stefan.voeth@thga.de).

Viktor A. Nikolaev - Senior Lecturer at the Department of Mine Electromechanics (mob. tel.: +007 90824140 19, e-mail: nikolaev.va.pstu@mail.ru).

Николаев Александр Викторович - кандидат технических наук, доцент кафедры горной электромеханики (моб. тел.: +007 9082414019 , e-mail: nikolaev0811@mail.ru). Контактное лицо для переписки.

Алыменко Николай Иванович - доктор технических наук, профессор, главный научный сотрудник лаборатории геотехнологических процессов и рудничной Алымено Никай Ива 10079127898086, - mail: nik

Каменских Антон Алексеевич - кандидат технических наук, научный сотрудник лаборатории геотехнологических процессов и рудничной газодинамики (моб. тел.: +007 90973169 44, e-mail: anton.kamenskikh@mi-perm.ru).

Фет Штефан Карлович - доктор технических наук, профессор, заведующий кафедрой технологии электроприводов и транспортных систем (моб. тел.: +490 234 9683642, e-mail: stefan.voeth@thga.de).

Николаев Виктор Александрович - старший преподаватель кафедры горной электромеханики (моб. тел.: +007 9082414019 , e-mail: nikolaev.va.pstu@mail.ru). 


\section{Introduction}

Safety rules [1] prescribe to heat the air sent to the shaft up to the temperature of not lower than $+2{ }^{\circ} \mathrm{C}$ in the cold season. At that, the whole volume of air entering the shaft across the entire section should have the same temperaure. However, studies conducted in $[2,3]$ have shown that these rules are not observed in practice. That is caused by the fact that two air streams enter the air-supplying barrel. Those streams are heated in a shaft heater, fed through a calorific channel and sucked through a pit head due to the general shaft depression. Consequently, the air coming from the shaft heater is heated to a much higher temperature than required, which often leads to a significant increase in set air temperature in a shaft. At the same time, there are areas in the air supplying shafts where the air temperature is slightly higher than $+2{ }^{\circ} \mathrm{C}$. That indicates low efficiency of the existing method of controlling the air preparation process and the possibility of violation of the temperature regime in a shaft.

An increase in temperature of the air supplied to the mine leads to an increase in energy consumption spent for shaft heater, i.e. to their irrational use $[4,5]$.

According to the [6], there are from 30 to $50 \%$ of the total electric energy consumed for ventilation by underground mining enterprises. Therefore, development of ways to increase energy efficiency of the main fan is another important task for the industry.

The situation described above, in addition to over-consumption of energy resources during the operation of a shaft heater and deterioration of safety conditions of production, causes an associated problem such as occurrence of the negative general mine natural draft [7-14]. That happens when the warm air injected into the supplying shafts tends to rise upward and cooled air in mine tends to lower down. This problem is relevant for shallow (up to $500 \mathrm{~m}$ or less) underground mining enterprises.

Besides, there is a problem characteristic of an inflate method such as occurrence of external air leaks [15], caused by the reason given next. Air is fed through the air supply shafts 1 to the mine by the discharge created by the main fan 2 located on the ventilation shaft 3 (Fig. 1). In addition to the air inflated into the mine, in such a ventilation scheme external air is also sucked into the main fan channel 4 through the mouth of the ventilation shaft 5 , which, when mixed with the total flow, is again discharged into the atmosphere. Therefore, in addition to useful work (fresh air injection), the main fan performs useless work, caused by external air inflation (external leaks).

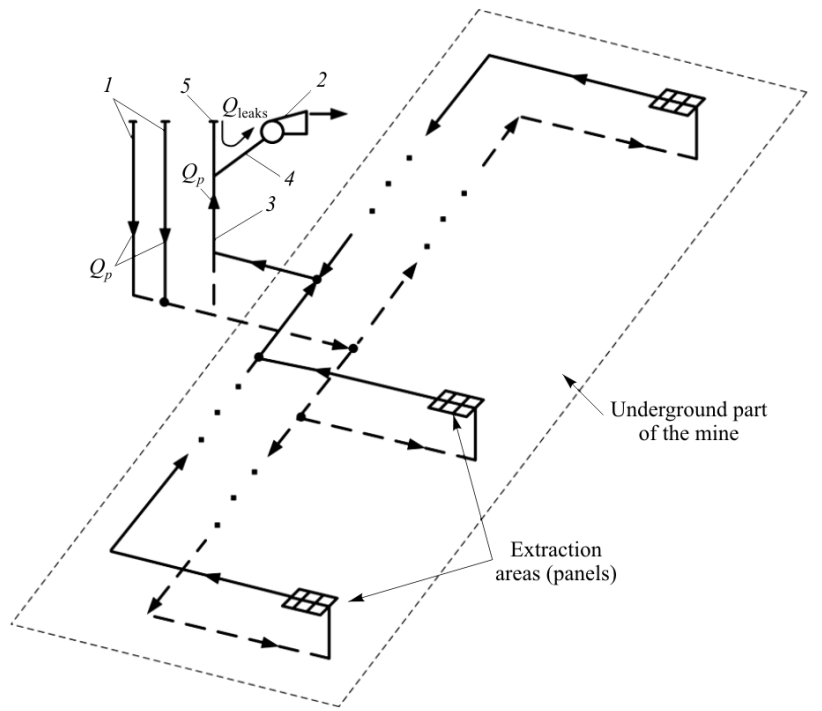

Fig. 1. Simplified scheme of mine ventilation that works on the inflate method

The magnitude of leaks (on example of potash mines), according to [16], is in the range of 9 to $51 \%$, i.e. there are mines where efficiency of the main fan is only $49 \%$. In this regard, a reduction of external leaks is one of the main directions in a complex of measures to reduce the costs of mining enterprises for ventilation of underground mining enterprise.

\section{Description of the proposed method of ventilation and air preparation}

In order to improve the efficiency of air preparation and reduce the cost of electricity consumed by the main fan, it was proposed in [17] to install an air curtain in the air supply and ventilation shafts (Fig. 2). A curtain in an air supply shaft has to ensure a reduction in the infiltration (suction) of the outside cold air through the overhead building. In this case less energy required for the work of a shaft heater. As a result, it will ensure normalization of the air mixing process in a shaft $[18,19]$. An air curtain in the ventilation shaft is necessary to reduce external air leaks [15].

Effectiveness of the process against the external air leaks (suckers) directly depends on the choice of the location of the air curtain in a shaft, parameters of fans that consists it of, and their mutual arrangement. 
A double side curtain was previously considered ineffective, because external air leakages in the ventilation shaft decreased slightly [15]. The reason for low efficiency of the

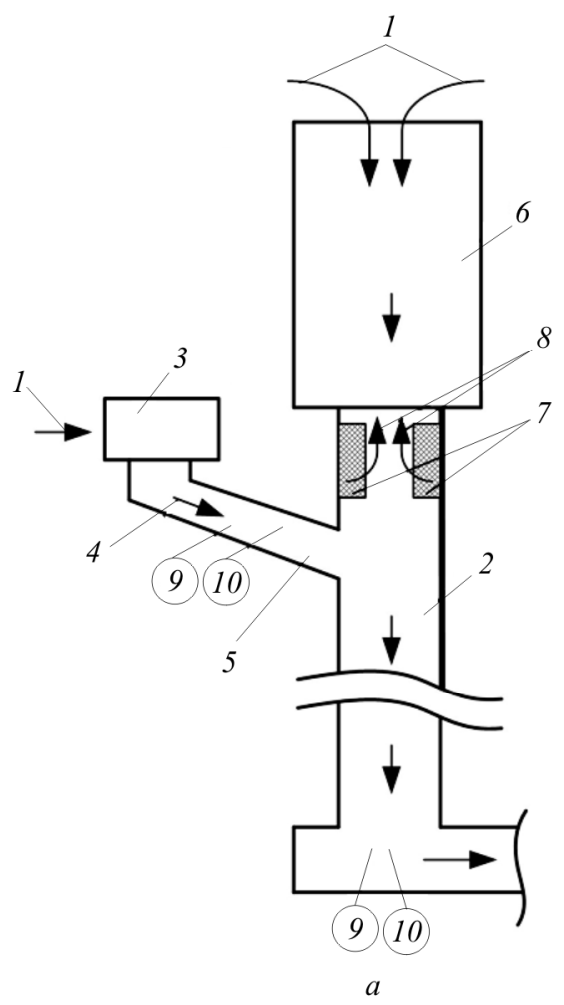

air curtain is that the air flows from fans are directed against each other and interfere with each other. In this case, almost no energy remains to counteract external air leaks in the air curtain.

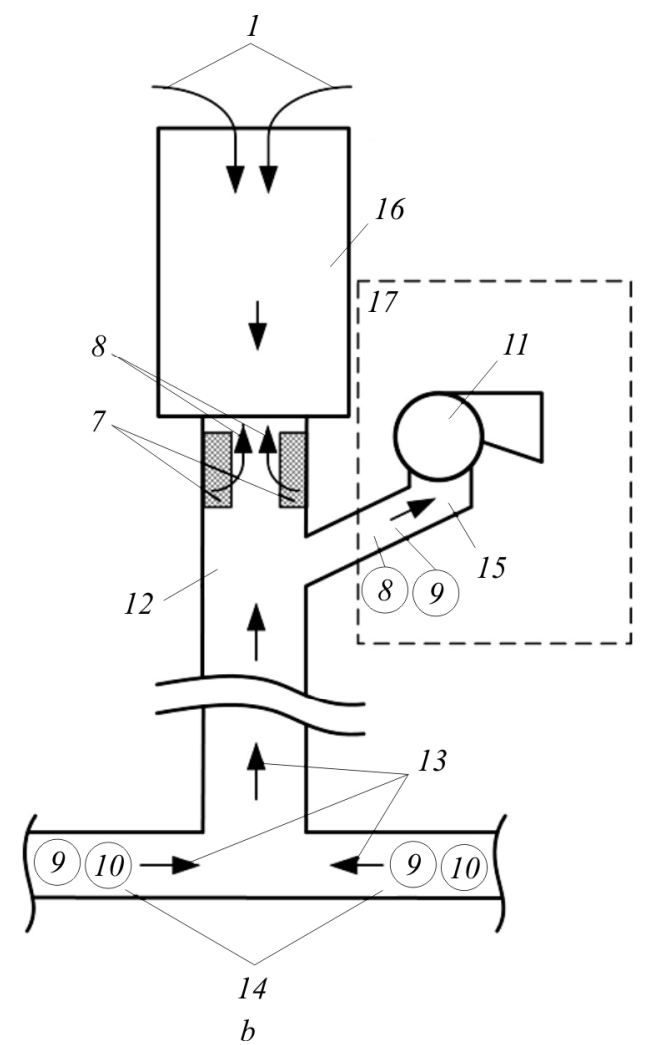

Fig. 2. Ventilation and air preparation according to the proposed method: $a$ - air curtain in the air supply shaft; $b$ - air curtain in the ventilation shaft: 1 - outside air (cold); 2 - air supplying shaft; 3 - shaft air heater; 4 - heated air; 5 - heater channel; 6 - pit head of air supplying shaft; 7 - air curtain; 8 - air discharged from the air curtain; 9 - the gauge of air rate; 10 - temperature and pressure (or density meter); 11 - main fan; 12 - ventilating shaft; 13 - air passing from the ventilation shaft; 14 - main ventilation excavations; 15 - main fan channel; 16 - pit head of ventilation shaft; 17 - surface complex of the main fan

In order to solve this problem, it was suggested in [20] that the flows of counter-directed fans have to be separated by a partition located in the shaft and the air streams have to be directed at a certain angle $\alpha$ (Fig. 3).

In order to reduce external air leaks through the mouth of the shaft, air curtain fans have to provide the necessary output and pressure. For that, for example, a fan of local ventilation of VME-6 of nonexplosive design can be used. That is used in mines for ventilation of spur excavations. If requested, the fan can be manufactured with a noise silencer.

There are several methods for calculating air curtains based on different approaches [21-24], which for many years remain unchanged. The task of these methods is to determine the speed of the air flow behind the curtain and establish the relationship between the speed and air flow inside that. For example, the velocity in [25] is found by

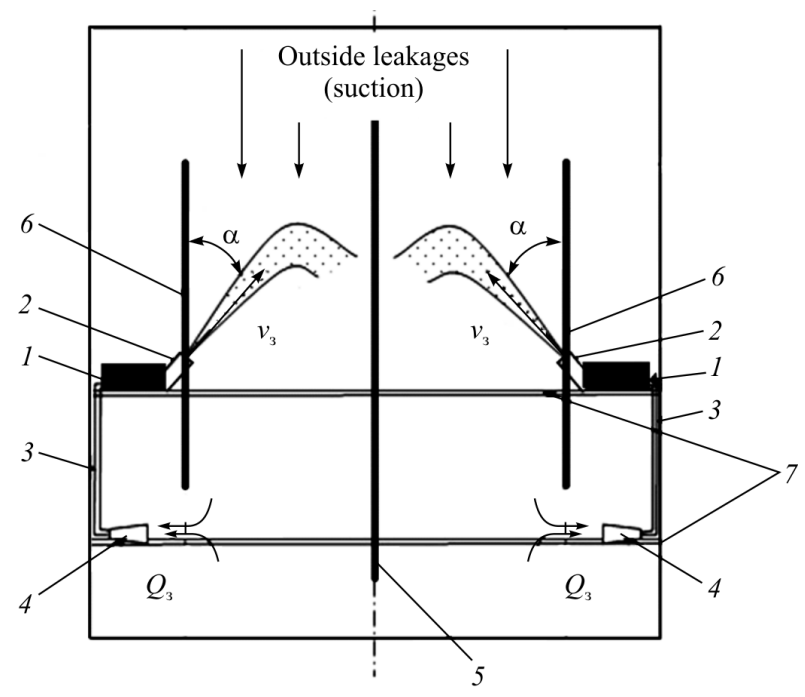

Fig. 3. Principle of the air curtain at the shaft throat: 1 - fans of the curtain; 2 - air suppluing boxes; 3 - pipelines (air ducts); 4 - intake of air; 5 - longitudinal partition; 6 - longitudinal partitions (along the perimeter of the section in the light); 7 - level of armour shaft 
adding the velocities of the air and flow jet that hits the curtain. The law of conservation of momentum is used in [24]. At that, usually it is considered that the velocity of the air flow entering the curtain is known [24-27].

Next, the required capacity and pressure of the fan installed on each half of the air curtain are calculated.

\section{The procedure for calculating the parameters of air curtain fans}

Initially, when determining the parameters of the air curtain, it is necessary to set the following initial data that is as follows:

1. The cross-section of the shaft at the installation site of a curtain (clear cross-section of the shaft) $S_{\text {shaft }}, \mathrm{m}^{2}$.

2. Average speed of the air flow without regards to the action of the air curtain $v_{0}$ and required in respect to its action $v_{1}, \mathrm{~m} / \mathrm{s}$.

3. Length of a shaft section $L_{\text {shaft }}$ that fans of the air curtain are installed on.

Value of mine ventillation pressure drop $(\mathrm{Pa})$ on a shaft section between junction with a main fan channel (a heater channel) and the surface is determined by the formula

$$
h_{0}=\frac{a P_{\text {shaft }} L_{\text {shaft }} v_{0}}{S_{\text {shaft }}^{2}},
$$

where $a$ is for a coefficient determining the type of the shaft (cage, skip) $[5,28] ; P_{\text {shaft }}$ is for perimetr of the shaft at the installation site of a curtain (clear cross-section of the shaft), $\mathrm{m}$.

Depending on how much external air leakage (suction) it is supposed to be reduced, the value that it is necessary to increase the aerodynamic drag by $\left(\mathrm{N} \cdot \mathrm{s}^{2} / \mathrm{m}^{8}\right)$ at the shaft section between the junction with a main fan (a heater channel) and the surface is determined.

$$
\Delta R_{\text {shaft }}=\frac{R_{\text {shaft }}\left(Q_{0}^{2}-Q_{1}^{2}\right)}{Q_{1}^{2}},
$$

where $R_{\text {shaft }}$ is for aerodynamic resistance of a shaft section between the junction with a main fan (a heater channel) and the surface, $\mathrm{N} \cdot \mathrm{s}^{2} / \mathrm{m}^{8}[5,28]$, $R_{\text {shaft }}=\frac{a P_{\text {shaft }} L_{\text {shaft }}}{S_{\text {shaft }}^{3}} ; Q_{0}$ is for volume rate of external air leakages (suction) in case of no air curtain, $\mathrm{m}^{3} / \mathrm{s}, Q_{0}=v_{0} S_{\text {shaft }} ; Q_{1}$ is for volume rate of external air leakages (suction) at the required air speed $\left(v_{1}\right)$ on current section, $\mathrm{m}^{3} / \mathrm{s}, Q_{1}=v_{1} S_{\text {shaft }}$.

The required air velocity $(\mathrm{m} / \mathrm{s})$ outlet from the air curtain fan slot is determined by the formula

$$
v_{\mathrm{a} . \mathrm{c}}=\sqrt{\frac{G_{2} v_{2}}{2 \rho_{\mathrm{a} . \mathrm{c}} S_{\mathrm{s}}}}=\sqrt{\frac{\left(G_{0} v_{0}-G_{1} v_{1}\right)}{2\left(0,465 P_{\mathrm{a} . \mathrm{c}} /\left(273,15+t_{\mathrm{a} . \mathrm{c}}\right)\right) S_{\mathrm{s}}}},
$$

where $G_{i}$ is for the air mass flow rate at the $i$-th point, $\mathrm{kg} / \mathrm{s}, G_{i}=Q_{i} \rho_{i} ; G_{0}, G_{1}$ and $G_{2}$ are for mass flow rate of external air leakages (suction), with no action of the air curtain, with its action and outgoing from the air curtain, $\mathrm{kg} / \mathrm{s} ; S_{\mathrm{s}}$ is for the surface of a slot of the air curtain fan through which the air flow is discharged; $\rho_{\mathrm{a} . \mathrm{c}}, P_{\mathrm{a} . \mathrm{c}}, t_{\mathrm{a} . \mathrm{c}}$ and $v_{\text {a.c }}$ are for density $\left(\mathrm{kg} / \mathrm{m}^{3}\right)$, pressure $(\mathrm{mmHg})$ and temperature $\left({ }^{\circ} \mathrm{C}\right)$ of the air, outlet from the air curtain, and its speed $(\mathrm{m} / \mathrm{s})$.

In the case when temperature and air pressure can not be determined, air density is assumed equal to $1,2 \mathrm{~kg} / \mathrm{m}^{3}$.

Performance of the air curtain is regulated by changing the area of the slot of $S_{\mathrm{s}}$ and/or by changing the air discharge angle from its fans. A frequency-controlled fan control drive can also be used.

\section{Results of simulation of the air preparation process using the air curtain in the air supply shaft}

Prior to the use of an air curtain in an air supply shaft, it is necessary to determine the effectiveness of the proposed method, for which the SolidWorks Flow Simulation software used for mathematical modelling of air curtain effect on the ventilation and air preparation process was performed in the package [29].

The Fig. 4 shows the results of modeling the processes of air preparation according to the method adopted currently (Fig. $4 a$ ) and using the air curtain (Fig. 4b).

As it seen from the figure, the proposed method allows to solve the previously mentioned problems arising during air preparation.

There are no zones with a temperature close to $+2{ }^{\circ} \mathrm{C}$ in the air supply shaft when using an air curtain. That means the threat of violation of safety rules is eliminated. At the same time, a shaft heater will require a smaller amount of energy resources, i.e. cost of air preparation will be reduce. In comparison with the volume of energy resources 
used for operation of a shaft heater, the costs of electric power used to operate the air curtain are incommensurably small.

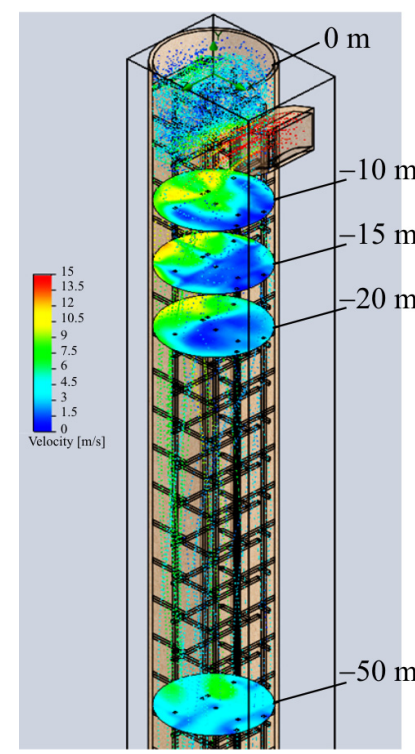

$a$

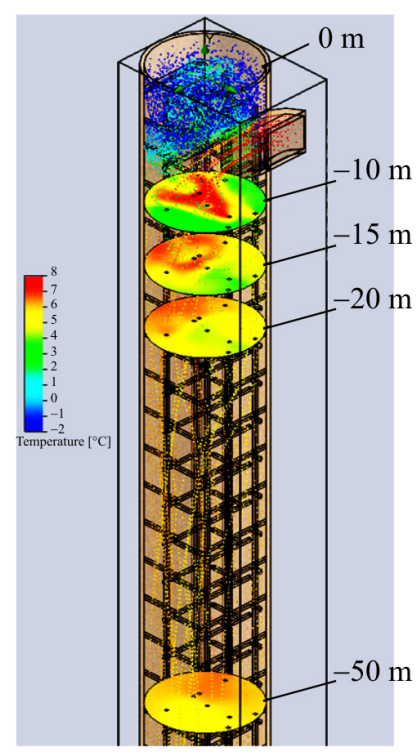

$b$
Fig. 4. Distribution of air temperature along the crosssection of the air supplying shaft at different depths by mixing cold and warm air using an air curtain installed at the shaft throat: cold air $-20{ }^{\circ} \mathrm{C}\left(20 \mathrm{~m}^{3} / \mathrm{s}\right)$, warm air $+8{ }^{\circ} \mathrm{C}\left(147 \mathrm{~m}^{3} / \mathrm{s}\right): a$ - with no air curtain in the air supply shaft; $b$ - air curtain in the ventilation shaft

Air heated unifirmly will reduce the overall value of air temperature throughout the section of the air supply shaft. In that case, either negative temperature drops between the shafts will be

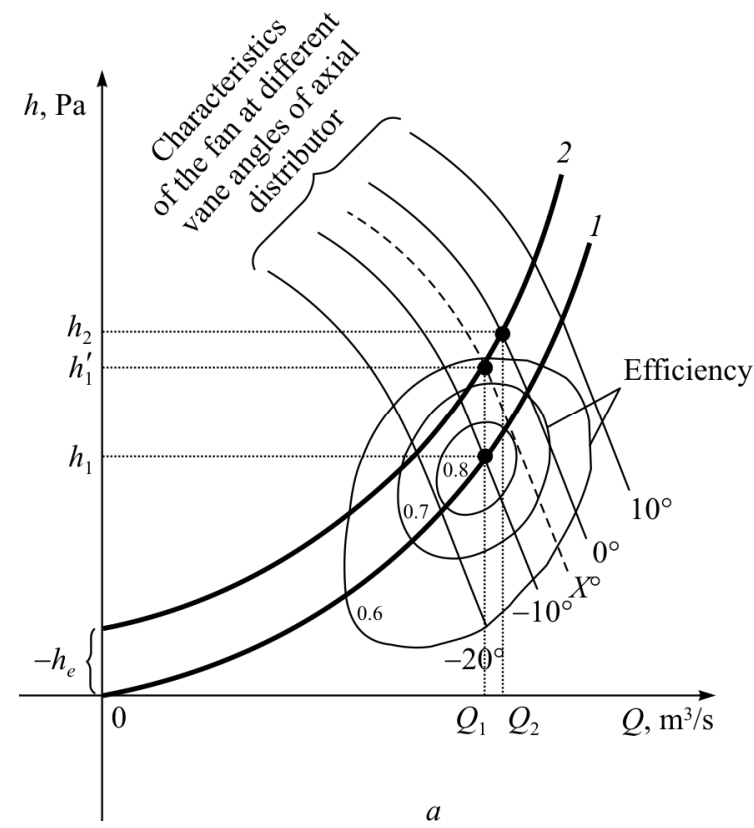

decreases or their direction will be reversed (positive temperature drops). Reducing the volume of air supplied to the mine will lead to the fact that the operating mode of the main fan will need to be transferred to the area of higher pressures. Under the action of positive natural draft, on contrary, a greater volume of air will be supplied to the mine. That means the operating mode of the main fan can be switched to the lower pressure range.

There is a similar situation occure when adjusting for the reason described next. In case there is no general mine natural draft (general mine temperature drop), curve of mine characteristics occupies a certain position 1 (Fig. 5). At that, the main fan should provide an air supply $Q_{1}$. An operating mode of the main fan is in this case is chosen according to the operating point (the point of intersection of the curves of mine characteristics and fan characteristics) that falls into the area of maximum efficiency.

The change in the absolute value of general natural draft will lead to the change in position of the curve of the mine to a certain position 2 (with a negative general natural draft on the Fig. $5 a$, with a positive general natural draft on the Fig. $5 b$ ).

Switching of the fan to another characteristic will result to the change in its performance: with negative natural general mine draft impact $\left(-h_{e}\right) 0^{\circ}$ (see. Fig. 5a); with positive natura general mine draft impact $\left(+h_{e}\right)-10^{\circ}$ (see. Fig. $5 b$ ). At such a regulation, an amount of air $Q_{2}$ will be supplied to

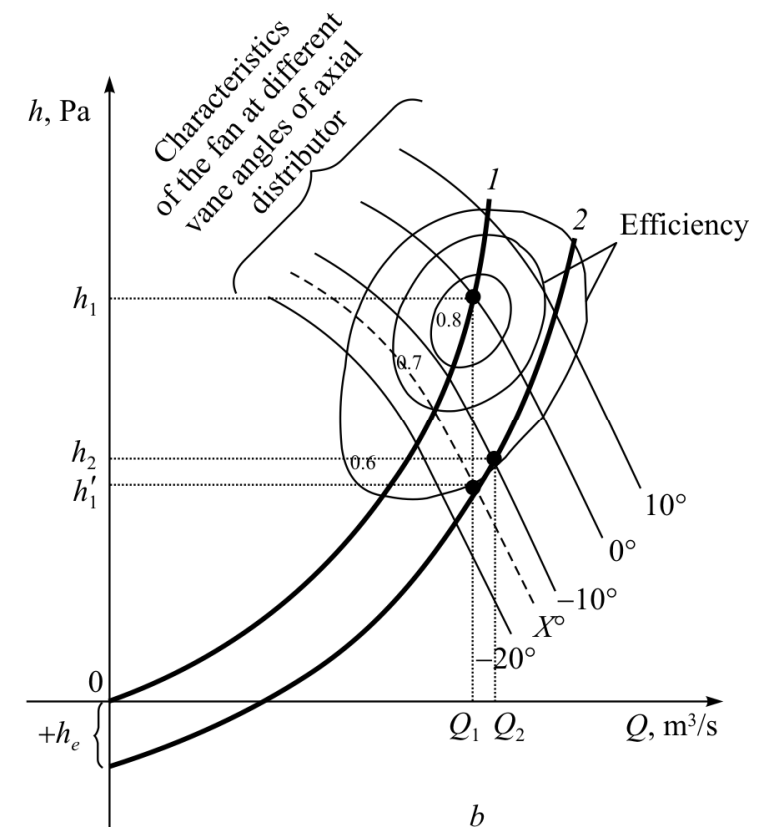

Fig. 5. Change in a position of the curve of mine characteristics: $a$ - under the action of negative general mine natural draft; $b$ - under the action of a positive general mine natural draft 
the mine more than the required $Q_{1}$, which entails additional energy costs. To avoid additional costs of electricity is possible by adjusting the angle of installation of an axial distributor to a certain position $\mathrm{X}^{0}$ (see Fig. 5). However, in terms of execution it is quite difficult. Taking into account the fact that the general mine natural draft changes constantly and fairly within a wide range [12], it can give an error when adjusting the angle of installation of axial distributor's blades. In addition, switching of the fan to another operating characteristic will inevitably decrease the efficiency (see Fig. 5). Due to that, an axial distributor will consume more electricity.

Changes in performance of the main fan can be achieved by adjusting the rotational speed of a fan impeller. For that an adjustable electric drive can be used. Performance of an electric drive will maintain required capacity due to speed and current feedback [30]. In this case, a drive control system will be adjusted so that the fan operates at the maximum efficiency. However, such regulation ensure overall natural draft that will have a significant impact on the operation of the main fan.

\section{Results of simulation of the ventilation process with the air curtain in the ventilation shaft}

During the mathematical modeling of the operation of the air curtain in the ventilation shaft (Fig. 6), it was established that under the accepted conditions external air leakages will be decreased from

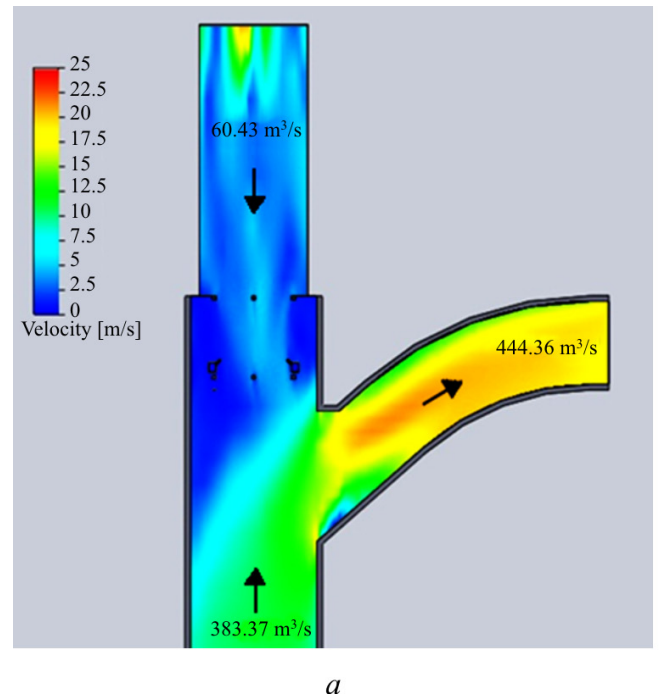

60.43 to $26.27 \mathrm{~m}^{3} / \mathrm{s}$ (by $43.5 \%$ ), and $444.36 \mathrm{~m}^{3} / \mathrm{s}$ will be needed for performance of the main fan instead of $409,46 \mathrm{~m}^{3} / \mathrm{s}$.

Due to the change in a structure of air flow in the region of air curtain two recirculation circuits are created. Circuits provide additional aerodynamic resistance at the throat of ventilation shaft from zero to the junction with the ventilation channel, thereby reducing the amount of external leaks. In this case, the shaft ensures maximum efficiency of the air curtain.

Due to the change in a structure of air flow in the region of air curtain two recirculation circuits are created. Circuits provide additional aerodynamic resistance at the throat of ventilation shaft from zero to the junction with the ventilation channel, thereby reducing the amount of external leaks. In this case, the shaft ensures maximum efficiency of the air curtain:

- amount of air supplied to the mine should not be less than the estimated amount of air required for airing the mine;

- cost of an air curtain should not exceed the cost of the main fan for external air leakages;

- cost of one cubic meter of fresh air supplied to the mine should be minimal.

The Fig. 7 shows characteristics of the main fan, characteristics of the mine network, operating points without the action of the air curtain (operating point A) and with the reduction of surface leakages with the air curtain (operating point C).

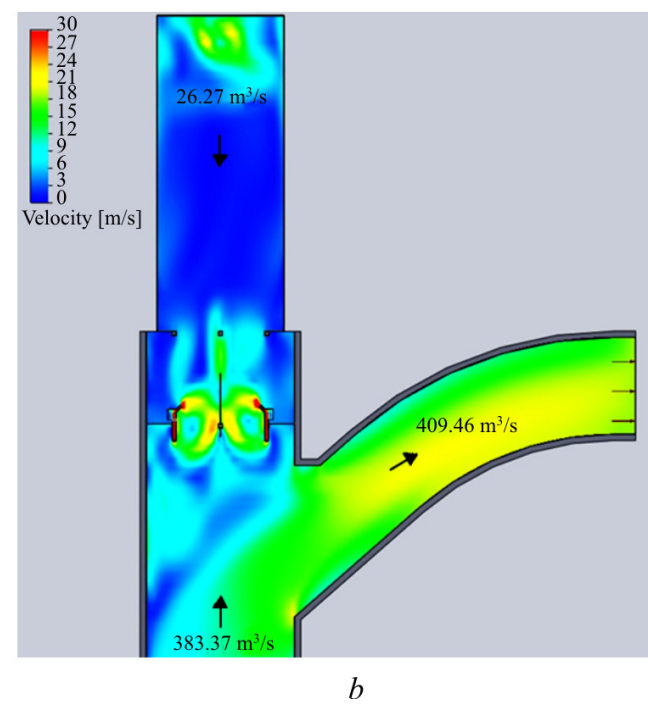

Fig. 6. Result of mathematical modeling of the distribution of air flows in the ventilation shaft: $a$ - with no air curtain in the air supply shaft; $b$ - with an air curtain in the ventilation shaft 


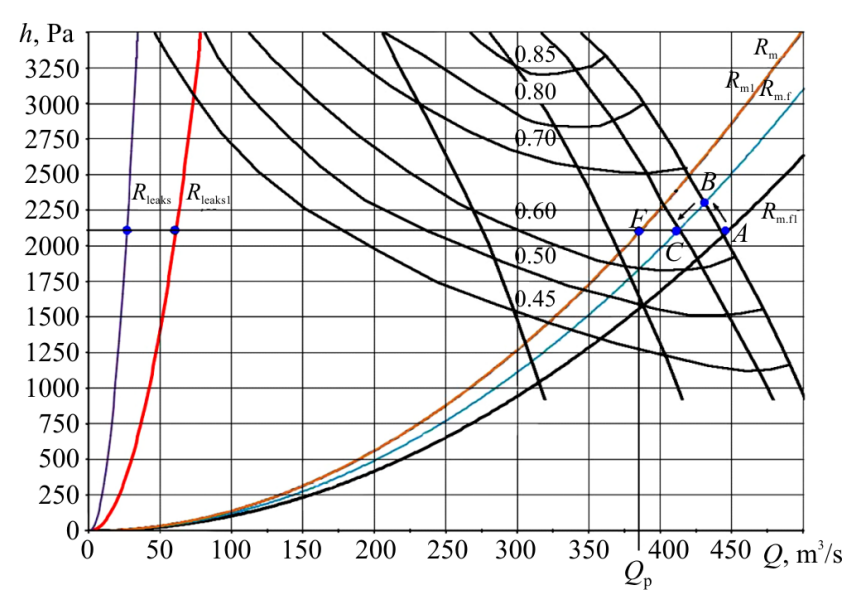

Fig. 7. Aerodynamic characteristics: $R_{\text {leaks } 1}$ is for aerodynamic resistance of external leakages of the air before the installation of air curtain; $R_{\text {leaks }}$ is for aerodynamic resistance of external leakages of the air after the installation of air curtain; $R_{\mathrm{m} . \mathrm{f} 1}$ is for aerodynamic resistance of the ventilation network before instalation of the air curtain; $R_{\mathrm{m} . \mathrm{f}}$ is for aerodynamic resistance of the ventilation network after instalation of the air curtain; $R_{\mathrm{m}}, R_{\mathrm{m} 1}$ are for aerodynamic resistance of the mine before and after instalation of the air curtain; $A, B, C$ are for fan operating points for various operating modes; $F$ is for the amount of fresh air entering the mine

Several results are obtained by the action of air curtain such as aerodynamic resistance of the shaft section increases from zero to the junction with the ventilation shaft, which increases the aerodynamic resistance of external air leakages from $R_{\text {leaks } 1}$ to $R_{\text {leaks }}$ (see Fig. 7). At the same time, the aerodynamic resistance of the mine $R_{\mathrm{m}}, R_{\mathrm{m} 1}$ remains the same and the aerodynamic resistance of the ventilation network increases from $R_{m . f 1}$ to $\mathrm{R}_{\mathrm{m} . \mathrm{f}}$ which the main fan operates for.

The operating point $A$ of the main fan propeller moves along the aerodynamic characteristic of the fan to the point $B$. After the movement of the operating point of the the main fan propeller $B$ to point $C$ by changing the angle of installation of the main fan vanes, the amount of fresh air that enters the mine $Q_{\mathrm{m}}$ remains the same $(F)$ and consumed electric power of the main fan decreases.
The amount of electricity $(\mathrm{kWh})$ saved as a result of the air curtain in the ventilation shaft, according to [31], is determined by the formula

$$
N_{\mathrm{s}}=\frac{T}{1000 \eta_{\mathrm{m}}}\left[\frac{Q_{\mathrm{m} . \mathrm{f}} h_{\mathrm{m} . \mathrm{f}}}{\eta_{\mathrm{m} . \mathrm{f}}}-\frac{Q_{\mathrm{m} . \mathrm{f}}^{\prime} h_{\mathrm{m} . \mathrm{f}}^{\prime}}{\eta_{\mathrm{m} . \mathrm{f}}}\right]-\frac{2 T Q_{\mathrm{a} . \mathrm{c}} h_{\mathrm{a} . \mathrm{c}}}{1000 \cdot \eta_{\mathrm{m} . \mathrm{c}} \eta_{\mathrm{a} . \mathrm{c}}},
$$

where $T$ is for the fan operating time per year, $\mathrm{h}$; $\eta_{m}$ is for the efficiency of the main fan electric motor, p.u.; $Q_{\mathrm{m} . \mathrm{f}}, h_{\mathrm{m} . \mathrm{f}}$ are for efficiency of the main fan, $\mathrm{m}^{3} / \mathrm{s}$, and its pressure, $\mathrm{Pa} ; Q_{\text {a.c }}, h_{\mathrm{a} . \mathrm{c}}$ are for efficiency of the air curtain propeller, $\mathrm{m}^{3} / \mathrm{s}$, and its pressure, $\mathrm{Pa} ; \eta_{\mathrm{m} . \mathrm{c}}$ is for efficiency of the electric motor of the air curtain, p.u.; $\eta_{\text {m.c }}$ is for the static efficiency of the air curtain propeller, p.u.

For each specific case the value of the saved energy have to be calculated. However, it is obvious that use of the air curtain in the ventilation shaft in order to increase the energy efficiency of ventilation is powerful.

\section{Conclusion}

It was established during the mathematical modeling that there is almost uniform heated air observed on its cross section when an air curtain is used for air preparation in an air supplying shaft. At the same time, it is possible to lower the temperature of the outgoing flow from the main fan by reducing the volume of sucked air through the supernumerary building of the air supplying shaft. As a result of that energy costs spent for air preparation is reduced.

By reducing the temperature of air entered the air supply shafts, negative (increasing positive) thermal depressions (general mine natural draft) will decrease between them. As a result, it is possible to reduce the main fan performance.

In addition, reduce in external air leakages allows reducing the productivity of the mine while maintaining the supply of the required air volume in the mine. Decrease in leakages can also be achieved by instalation of the air curtain in the ventilation shaft.

Thus, the proposed method of ventilation will not only allow air preparation in a safe mode, but also reduce energy costs.

\section{References}

1. Federal'nye normy i pravila $\mathrm{v}$ oblasti promyshlennoi bezopasnosti "Pravila bezopasnosti pri vedenii gornykh rabot i pererabotke tverdykh poleznykh iskopaemykh" [Federal rules and regulations in the field of industrial safety "Safety rules for mining and processing of solid minerals"]. Seriia 03, iss.78. Moscow, Nauchno-tekhnicheskii tsentr issledovanii problem promyshlennoi bezopasnosti, 2014, $276 \mathrm{p}$.
2. Alymenko N.I., Nikolaev A.V., Kamenskikh A.A., Petrov A.I. Rezul'taty matematicheskogo modelirovaniia smeshivaniia kholodnogo i teplogo potokov vozdukha $\mathrm{V}$ vozdukhopodaiushchem stvole rudnika [Results of mathematical modeling of mixing cold and warm air flows in the air supply shaft of the mine]. Gornoe oborudovanie i elektromekhanika, 2014, no.12, pp.31-33. 
3. Alymenko N.I., Nikolaev A.V., Kamenskikh A.A., Tronin A.P. Rezul'taty issledovaniia sistemy ventiliatsii rudnika BKPRU-2 v kholodnoe vremia goda [Results of a study of the BKPRU-2 mine ventilation system in the cold season]. Vestnik Permskogo universiteta. Geologiia, 2011, no.3, pp,89-96.

4. Alymenko N.I., Kamenskikh A.A., Nikolaev A.V., Petrov A.I. Numerical modeling of heat and mass transfer during hot and cool air mixing in air supply shaft in underground mine. Eurasian mining, 2016, no.2, pp.45-47. DOI: $10.17580 / \mathrm{em} .2016 .02 .11$

5. Nikolaev A.V. Upravlenie teplovymi depressiiami $\mathrm{v}$ sistemakh ventiliatsii kaliinykh rudnikov [Management of thermal depressions in potash mine ventilation systems]. Abstract of Ph. D. thesis. Perm', 2012, 20 p.

6. Starkov L.I., Zemskov A.N., Kondrashev P.I. Razvitie mekhanizirovannoi razrabotki kaliinykh rud [Development of mechanized development of potash ores]. Perm', Izdatel'stvo Permskogo gosudarstvennogo tekhnicheskogo universiteta, 2007, $522 \mathrm{p}$.

7. Bruce W.E. Natural draft: its measurement and modeling in underground mine ventilation systems. US, Dept. of Labor, Mine Safety and Health Administration, 1986, 34 p.

8. Linden P.F. The fluid mechanics of natural ventilation. Annual Review of Fluid Mechanics, 1999, vol.31, pp.201-238. DOI: 10.1146/annurev.fluid.31.1.201

9. Jianwei Cheng, Yan $\mathrm{Wu}$, Haiming $\mathrm{Xu}$, Jin Liu, Yekang Yang, Huangjun Deng, Yi Wang. Comprehensive and integrated mine ventilation consultation model. Tunneling and Underground Space Technology, 2015, vol.45, pp.166-180. DOI: 10.1016/j.tust.2014.09.004

10. Van Ulden, Holtslag A. Estimation of atmospheric boundary layer parameters for diffusion applications. J. Clim. Appl. Meteorol., 1985, vol.24, pp.1196-1207. DOI: 10.1175/1520-0450(1985)024<1196:EOABLP > 2.0.CO;2

11. Alymenko N.I., Nikolaev A.V. Influence of mutual alignment of mine shafts on thermal drop of ventilation pressure between the shafts. Journal of Mining Science, 2011, vol.47, no.5, pp.636-642. DOI: 10.1134/S1062739147050121

12. Lyal'kina G.B., Nikolaev A.V. Natural draught and its direction in a mine at the preset confidence coefficient. Journal of Mining Science, 2015, vol.51, no.2, pp.342-346. DOI: 10.1134/S1062739115020180

13. Gendler S.G. The justification of new technique ventilation at contraction of working with two exits in soil surface. Eurasian Mining, 2016, no.2, pp.41-44. DOI: 10.17580/em.2016.02.10

14. Krainov, A.V., Pashkov, E.N., Ponomaryov, A.V. Conjugate heat transfer in the interaction of the viscous liquid with technological elements of energy systems in conditions of their internal contour moving. Advanced Materials Research, 2014, 1040, pp.876-880. DOI: 10.4028/www.scientific.net/AMR.1040.876

15. Kamenskikh A.A. Razrabotka metodov kontrolia i snizheniia poverkhnostnykh utechek vozdukha na rudnikakh [Development of methods for control and reduction of surface air leaks in mines]. Abstract of Ph. D. Thesis. Пермь, 2011, 19 p.
16. Alymenko N.I., Kamenskikh A.A., Nikolaev A.V., Nikolaev V.A., Petrov A.I. Vneshnie utechki vozdukha na kaliinykh rudnikakh VKMKS [External air leaks at potash mines VKMKS]. Aktual'nye problemy povysheniia effektivnosti i bezopasnosti ekspluatatsii gornoshakhtnogo $i$ neftepromyslovogo oborudovaniia, 2016, no.1, pp.194-201.

17. Nikolaev A.V., Alymenko N.I., Nikolaev V.A., Kamenskikh A.A. Sposob provetrivaniia podzemnogo gornodobyvaiushchego predpriiatiia [Method for ventilating an underground mining enterprise]. Patent 2601342. Russian Federation.

18. Nikolaev A.V., Alymenko N.I., Kamenskikh A.A., Nikolaev V.A., Petrov A.I. Povyshenie effektivnosti protsessa vozdukhopodgotovki za schet ispol'zovaniia vozdushnoi zavesy $\mathrm{v}$ vozdukhopodaiushchem stvole [Improving the efficiency of the air preparation process by using an air curtain in the air supply barrel]. Aktual'nye problemy povysheniia effektivnosti $i$ bezopasnosti ekspluatatsii gornoshakhtnogo $i$ neftepromyslovogo oborudovaniia, 2016, no.1, pp.209-213.

19. Nikolaev A., Alymenko N., Kamenskih A., Nikolaev V.The results of air treatment process modeling at the location of the air curtain in the air suppliers and ventilation shafts. E3S Web of Conferences, 2017, vol. 15: The 1st Scientific Practical Conference "International Innovative Mining Symposium (in memory of Prof. Vladimir Pronoza)", $7 \mathrm{p}$. DOI: $10.1051 / \mathrm{e} 3$ sconf/20171502004

20. Alymenko N.I., Kamenskikh A.A. Ustroistvo dlia sozdaniia vozdushnoi zavesy [Device for creating an air curtain]. Patent 136490 Russian Federation.

21. El'terman V.M. Vozdushnye zavesy [Air curtains]. Moscow, Mashinostroenie, 1966, 164 p.

22. Tatarchuk G.T. Utochnennaia metodika rascheta vozdushnykh zaves [Refined methodology for calculating air curtains]. Otoplenie i ventiliatsiia promyshlennykh i sel'skokhoziaistvennykh zdanii. Moscow, 1966, no.16, pp.66-72.

23. Mac Farlane D. Ventilation engineering. Belfast, $1965,324 \mathrm{p}$.

24. Sychev A.T. K raschetu vozdushnykh zaves [To the calculation of air curtains]. Vodosnabzhenie $i$ sanitarnaia tekhnika, 1974, no.2, pp.22-24.

25. Shepelev I.A. Osnovy rascheta vozdushnykh zaves, pritochnykh strui i poristykh fil'trov [Basics of calculating air curtains, supply air jets and porous filters]. Moscow, Stroiizdat, 1950, 150 p.

26. Timukhin S.A., Belov S.V. Opredelenie optimal'noi skorosti vozdukha $\mathrm{V}$ kanalakh glavnykh ventiliatornykh ustanovok [Determination of the optimum air velocity in the ducts of the main fan units]. Izvestiia vuzov. Gornyi zhurnal, 1981, no.7, pp.89-91.

27. Korennoi K.N., Mokretsov G.M., Korennoi N.N., Panov I.S., Iudin S.I., Tokmakov V.V. Sostoianie provetrivaniia shakht Urala [The state of ventilation of the mines of the Urals]. Izvestiia vuzov. Gornyi zhurnal, 2006, no.4, pp.47-50. 
28. Mokhirev N.N., Rad'ko V.V. Inzhenernye raschety ventiliatsii shakht. Stroitel'stvo. Rekonstruktsiia. Ekspluatatsiia [Engineering calculations of mine ventilation. Building. Reconstruction. Exploitation]. Moscow, Nedra-Biznestsentr, 2007, 324 p.

29. Aliamovskii A.A., Sobachkin A.A., Odintsov E.V. et al. SolidWorks 2007/2008. Komp'iuternoe modelirovanie $\mathrm{V}$ inzhenernoi praktike [SolidWorks 2007/2008. Computer modeling in engineering practice]. Saint Petersburg, BKhV-Peterburg, 2008, 1040 p.

30. Vasil'ev E.M., Nikolaev A.V., Korolev N.A. Sistema upravleniia elektroprivodom nagnetatel'nykh ventiliatorov i setevogo nasosa dlia podderzhaniia teplovogo rezhima $\mathrm{v}$ shakhtnykh stvolakh [The control system for the electric drive of the blowers and the network pump for maintaining the thermal regime in the shafts]. Gornoe oborudovanie $i$ elektromekhanika, 2015, no.1(110), pp.20-24.

31. Alymenko N.I. Issledovanie raboty ventiliatornykh ustanovok glavnogo provetrivaniia i razrabotka meropriiatii po povysheniiu effektivnosti ikh ekspluatatsii primenitel'no $\mathrm{k}$ usloviiam kaliinykh rudnikov [Research of the operation of ventilating installations of main ventilation and development of measures to increase the efficiency of their operation in relation to the conditions of potash mines]. Ph. D. thesis. Leningrad, 1982, $229 \mathrm{p}$.

\section{Библиографический список}

1. Федеральные нормы и правила в области промышленной безопасности «Правила безопасности при ведении горных работ и переработке твердых полезных ископаемых». Серия 03. Вып. 78. / Науч.техн. центр исследований проблем промышленной безопасности. - М., 2014. - 276 с.

2. Результаты математического моделирования смешивания холодного и теплого потоков воздуха в воздухоподающем стволе рудника / Н.И. Алыменко, А.В. Николаев, А.А. Каменских, А.И. Петров // Горное оборудование и электромеханика. - 2014. - № 12. - С. 31-33.

3. Результаты исследования системы вентиляции рудника БКПРУ-2 в холодное время года / Н.И. Алыменко, А.В. Николаев, А.А. Каменских, А.П. Тронин // Вестник Пермского университета. Геология. - 2011. №. 3. - C. 89-96.

4. Numerical modeling of heat and mass transfer during hot and cool air mixing in air supply shaft in underground mine / N.I. Alymenko, A.A. Kamenskikh, A.V. Nikolaev, A.I. Petrov // Eurasian Mining. - 2016. № 2. - P. 45-47. DOI: 10.17580/em.2016.02.11

5. Николаев А.В. Управление тепловыми депрессиями в системах вентиляции калийных рудников: автореф. дис. ... канд. техн. наук. - Пермь, 2012. -20 с.

6. Старков Л.И., Земсков А.Н., Кондрашев П.И. Развитие механизированной разработки калийных руд. Пермь: Изд-во Перм. гос. техн. ун-та, 2007. - 522 с.

7. Bruce W.E. Natural draft: its measurement and modeling in underground mine ventilation systems / Dept. of Labor, Mine Safety and Health Administration. - US, 1986. - $34 \mathrm{p}$.

8. Linden P.F. The fluid mechanics of natural ventilation // Annual Review of Fluid Mechanics. - 1999. - Vol. 31. P. 201-238. DOI: 10.1146/annurev.fluid.31.1.201

9. Comprehensive and integrated mine ventilation consultation model / Jianwei Cheng, Yan Wu, Haiming $\mathrm{Xu}$, Jin Liu, Yekang Yang, Huangjun Deng, Yi Wang // Tunneling and Underground Space Technology. - 2015. Vol. 45. - P. 166-180. DOI: 10.1016/j.tust.2014.09.004

10. Van Ulden A.P., Holtslag A.M. Estimation of atmospheric boundary layer parameters for diffusion applications // J. Clim. Appl. Meteorol. - 1985. - Vol. 24. - P. 1196-1207. DOI: 10.1175/1520-0450(1985)024<1196:EOABLP > 2.0.CO;2
11. Alymenko N.I., Nikolaev A.V. Influence of mutual alignment of mine shafts on thermal drop of ventilation pressure between the shafts // Journal of Mining Science - 2011. - Vol. 47, № 5. - P. 636-642. DOI: $10.1134 / \mathrm{S} 1062739147050121$

12. Lyal'kina G. B., Nikolaev A.V. Natural draught and its direction in a mine at the preset confidence coefficient // Journal of Mining Science. - 2015. - Vol. 51, № 2. - P. 342-346. DOI: 10.1134/S1062739115020180

13. Gendler S. G. The justification of new technique ventilation at contraction of working with two exits in soil surface // Eurasian Mining. - 2016. - № 2. - P. 41-44. DOI: $10.17580 /$ em.2016.02.10

14. Krainov A.V., Pashkov E.N., Ponomaryov A.V. Conjugate heat transfer in the interaction of the viscous liquid with technological elements of energy systems in conditions of their internal contour moving // Advanced Materials Research. - 2014. - 1040. - P. 876-880. DOI: 10.4028/www.scientific.net/AMR.1040.876

15. Каменских А.А. Разработка методов контроля и снижения поверхностных утечек воздуха на рудниках: автореф. дис. ... канд. техн. наук / Горн. ин-т УрО РАН. Пермь, 2011. - 19 с.

16. Внешние утечки воздуха на калийных рудниках ВКМКС / Н.И. Алыменко, А.А. Каменских, А.В. Николаев, В.А. Николаев, А.И. Петров // Актуальные проблемы повышения эффективности и безопасности эксплуатации горношахтного и нефтепромыслового оборудования. 2016. - № 1. - С. 194-201.

17. Способ проветривания подземного горнодобывающего предприятия: пат. 2601342 Рос. Федерация, МПК E21F1/08; E21F3/00 / Николаев А.В., Алыменко Н.И., Николаев В.А., Каменских А.А.; заявл. 22.09.2015; опубл. 10.11.2016, Бюл. № 31. - 12 с.

18. Повышение эффективности процесса воздухоподготовки за счет использования воздушной завесы в воздухоподающем стволе / А.В. Николаев, Н.И. Алыменко, А.А. Каменских, В.А. Николаев, А.И. Петров // Актуальные проблемы повышения эффективности и безопасности эксплуатации горношахтного и нефтепромыслового оборудования. - 2016. - № 1. - С. 209-213.

19. The results of air treatment process modeling at the location of the air curtain in the air suppliers and ventilation 
shafts / A. Nikolaev, N. Alymenko, A. Kamenskih, V. Nikolaev // E3S Web of Conferences. - 2017. - Vol. 15: The 1st Scientific Practical Conference «International Innovative Mining Symposium (in memory of Prof. Vladimir Pronoza). - P. 7. DOI: 10.1051/e3sconf/20171502004

20. Устройство для создания воздушной завесы: пат. 136490 Рос. Федерация, МПК Е21F 1/16, F24F 9/00 / Алыменко Н.И., Каменских А.А.; заявл. 08.08.2013; опубл. 10.01.2014, Бюл. № 1. - 2 c.

21. Эльтерман В.М. Воздушные завесы. - М.: Машиностроение, 1966. - 164 с.

22. Татарчук Г.Т. Уточненная методика расчета воздушных завес // Отопление и вентиляция промышленных и сельскохозяйственных зданий. - М., 1966. - № 16. - C. 66-72.

23. Mac Farlane D. Ventilation Engineering. - Belfast, 1965. $-324 \mathrm{p}$.

24. Сычев А.Т. К расчету воздушных завес // Водоснабжение и санитарная техника. - 1974. - № 2. - С. 22-24.

25. Шепелев И.А. Основы расчета воздушных завес, приточных струй и пористых фильтров. - М.: Стройиздат, 1950. - $150 \mathrm{c}$.

26. Тимухин С.А., Белов С.В. Определение оптимальной скорости воздуха в каналах главных вентиляторных установок // Известия вузов. Горный журнал. - 1981. - № 7. - С. 89-91.

27. Состояние проветривания шахт Урала / К.Н. Коренной, Г.М. Мокрецов, Н.Н. Коренной, И.С. Панов, С.И. Юдин, В.В. Токмаков // Известия вузов. Горный журнал. - 2006. - № 4. - С. 47-50.

28. Мохирев Н.Н., Радько В.В. Инженерные расчеты вентиляции шахт. Строительство. Реконструкция. Эксплуатация. - М.: Недра-Бизнесцентр, 2007. - 324 с.

29. SolidWorks 2007/2008. Компьютерное моделирование в инженерной практике / А.А. Алямовский, А.А. Собачкин, Е.В. Одинцов [и др.]. - СПб.: БХВ-Петербург, 2008. - 1040 с.

30. Васильев Е.М., Николаев А.В., Королев Н.А. Система управления электроприводом нагнетательных вентиляторов и сетевого насоса для поддержания теплового режима в шахтных стволах // Горное оборудование и электромеханика. - 2015. - № 1 (110). С. 20-24.

31. Алыменко Н.И. Исследование работы вентиляторных установок главного проветривания и разработка мероприятий по повышению эффективности их эксплуатации применительно к условиям калийных рудников: дис. ... канд. тех. наук. - Л., 1982. - 229 с.

Please cite this article in English as:

Nikolaev A.V., Alymenko N.I., Kamenskikh A.A., Fet S.K., Nikolaev V.A. Results of modelling of mine ventilation with air curtain installed into downcast and upcast shafts. Perm Journal of Petroleum and Mining Engineering, 2017, vol.16, no.3, pp.291-300. DOI: $10.15593 / 2224-9923 / 2017.3 .10$

Просьба ссылаться на эту статью в русскоязычных источниках следующим образом:

Результаты моделирования процесса проветривания рудника при расположении воздушной завесы в воздухоподающем и вентиляционном стволах / А.В. Николаев, Н.И. Алыменко, А.А. Каменских, Ш. Фет, В.А. Николаев // Вестник Пермского национального исследовательского политехнического университета. Геология. Нефтегазовое и горное дело. - 2017. - Т.16, №3. C.291-300. DOI: 10.15593/2224-9923/2017.3.10 